\title{
Development of Functional Beverage (SanYa) from Fermented Medical Plants and Evaluation of Its Physiological Activities
}

\author{
Eun Kyung Cho', Hyo Ju Song, Hea Eun Cho, In Soon Choi and Young Ju Choi* \\ Department of Food and Nutrition, ${ }^{1}$ Department of Bio-Food Materials, ${ }^{2}$ Department of Life Science, Silla University, Busan 617-736, Korea
}

Received November 4, 2009 /Accepted December 6, 2009

\begin{abstract}
This study was investigated to analyze the contents of flavonoid compounds and the effects of fermentation on the physiological activities of medical plants, also known as SanYa (SY). Antioxidative activity of the fermented SanYa (FSY) was measured by using DPPH radical scavenging and SOD-like activity. DPPH radical scavenging and SOD-like activity of FSY were $94.3 \%$ and $45.0 \%$, respectively. Nitric oxide (NO) synthesis was increased 11 times through the addition of FSY. However, NO production of the macrophages RAW264.7 cells stimulated with lipopolysaccharide (LPS) was reduced to 56\% through the addition of FSY. FSY showed fibrinolytic activity and indicated about $69.8 \%$ and $73.7 \%$ of xanthine oxidase and angiotensin converting enzyme inhibitory activities, respectively. These results suggested that FSY plays a significant role in fibrinolytic activity and have strong xanthine oxidase and angiotensin converting enzyme inhibitory activities.
\end{abstract}

Key words : Fibrinolytic activity, ACE inhibition, antioxidative activity, nitric oxide, xanthine oxidase

\section{서 론}

지금까지의 약용식물 및 약재에 대한 연구는 주로 유기용매 로 특정성분을 추출하여 여러 가지 생리활성을 가지는 물질 탐색에 대한 연구와 효능이 우수하고 안전한 약물개발에 대한 연구로 수행되어 왔다. 또한 대체의약으로 천연물질에 대한 관심이 높아지면서 약용식물에 대한 과학적인 연구와 천연 의약품 개발에 더욱 많은 연구를 수행하고 있다. 이는 최근 생활수준의 향상으로 평균수명의 연장과 건강에 대한 관심이 높아지면서 그리고, 식습관에 기인하는 여러 가지 만성질환의 증가로 인해 더욱 더 항산화, 항암, 면역증진 및 혈행개선 등의 생리활성을 갖는 약용식물에 대한 연구가 진행되게 되었다 $[17,33]$. 특히, 건강음료 개발에 약용식물을 활용하고자 해 왔 는데, 현재 시판되고 있는 건강음료의 종류는 섬유소를 주로 한 변비예방과 정장작용을 돕는 것이거나 체중조절을 위한 것, 체내수분과 전해질공급을 위한 것이 대부분이며, 그 외 건강 보양을 위한 것 등이 개발되고 있다. 아직은 약용식물을 이용한 음료개발에 관한 연구가 일부 영역만을 다루고 있어 건강기능성 음료로 활용하기 위해서는 앞으로 다각적인 연구 가 요구된다.

이에 약용식물이 함유하고 있는 여러 가지 효소들을 활성화 시켜 다양한 생화학반응을 일으킴으로 해서 식물체의 성분들 이 소화 - 흡수되기 쉬운 형태로 전환될 수 있게 하여 새로운 생리기능을 하는 물질로 변화시키거나 유용성분이 증가한 음

*Corresponding author

Tel : +82-51-999-5459, Fax : +82-51-999-5457

E-mail : yjchoi@silla.ac.kr
료를 개발하는 것이 부각되고 있다. 효소를 이용한 식품개발 로는 미생물의 활동으로 유기화합물이 분해되면서 알코올, 유 기산, 탄산가스 등 분해산물을 생성하는 발효의 과정이 있다. 이는 오래전부터 이용되어 왔는데, 과실 전통발효의 경우가 해당된다. 주로 발효성 당이 다량 함유되어있는 과실을 발효 시켜 술로 많이 이용되어 왔는데[4], 탄수화물원이 부족할 경 우에는 발효원료에 설탕, 전분 등 탄수화물원을 첨가하여 발 효해왔다. 최근 들어 식품의 발효를 통해 생성되는 유기산 및 분해산물들이 건강에 좋다는 연구 결과 등이 발표되면서 발효 식품의 인기는 점점 높아지고 있는 실정이다[2,8]. 또한, 최근 의 정제가공식품은 제조과정에서 효소들이 대부분 파괴되며, 특히 식품보존제로 첨가되는 화학성분들은 효소활성을 약화 시키는 작용을 하므로 더욱 더 발효식품에 대한 관심이 고조 되고 있다.

본 연구에서는 한약방에서 유통되고 있는 약재들의 농약 및 약초의 독성문제 등을 극복하고, 면역기능 증진 및 혈행개선 효과가 현저한 다기능성 음료를 개발하기 위한 방안으로 19 가 지의 산야초를 발효시킨 후 발효음료의 항산화작용, 면역기능, 혈전분해력, $\mathrm{ACE}$ 활성억제 등의 생리활성을 연구하였다.

\section{재료 및 방법}

\section{시료 채취 및 발효}

본 실험에 사용된 실험 재료는 증류수 101 에 산야(민들레 $40 \mathrm{~g}$, 연자육 $40 \mathrm{~g}$, 솔잎 $30 \mathrm{~g}$, 참나리 $30 \mathrm{~g}$, 애쑥 $30 \mathrm{~g}$, 질경이 $30 \mathrm{~g}$, 뽕열매 $40 \mathrm{~g}$, 감초 $24 \mathrm{~g}$, 도라지 $9 \mathrm{~g}$, 쇠비름 $9 \mathrm{~g}$, 자소엽 $9 \mathrm{~g}$, 박하 $36 \mathrm{~g}$, 금불초 $9 \mathrm{~g}$, 오가피 $18 \mathrm{~g}$, 참마 $15 \mathrm{~g}$, 연뿌리 
$18 \mathrm{~g}$, 두충 $30 \mathrm{~g}$, 둥글레 $200 \mathrm{~g}$, 녹차잎 $100 \mathrm{~g})$ 와 다시마(100 $\mathrm{g}$ )및 미네랄 수(해양성심층수, $0.5 \%$ )는 부재료로 첨가하여 당 의 농도가 50.0 60.0 Brix가 되도록 설탕시럽을 넣은 후 발효 시켰다. 약 6개월 동안 발효 시킨 후 산야 발효액의 $\mathrm{pH} 5.2$ 였 고, 시료로 사용하기 위해 발효액은 여과하였으며 $4^{\circ} \mathrm{C}$ 에서 냉 장 보관하였다.

\section{전자공여능(Electron donation ability: $\mathrm{EDA}$ ) 측정}

전자공여능 측정은 Blois의 방법[5]에 따라서 각 시료의 DPPH (1,1-diphenyl- 2-picrylhydrazyl)에 대한 수소공여 효 과로 측정 하였다. 시료를 농도별로 희석하여 시료 $40 \mu \mathrm{l}$ 와 $1.5 \mathrm{mM} \mathrm{DPPH}$ 용액 $160 \mu 1$ 를 섞은 후, $37^{\circ} \mathrm{C}$ 에서 30 분 동안 반응시킨 다음 ELISA reader를 이용하여 $520 \mathrm{~nm}$ 에서 흡광도 를 측정하였다. 전자공여능(Electron donating ability, EDA) 은 $\mathrm{EDA}(\%)=($ 대조구흡광도-시료첨가구흡광도) / 대조구흡광 도 $\times 100$ 으로 계산하였다. 시료를 첨가하지 않은 대조그룹과 흡 광도차를 비교하여 프리라디칼의 제거활성을 백분율로 나타 내었다.

\section{세포배양}

마우스대식세포주인 RAW264.7 세포는 American Type Culture Collection (ATCC, Manassas, VA. USA)에서 구입하 였으며, 세포배양에 사용된 배지인 RPMI 1640 medium (Eagle's MEM)과 fetal bovine serum (FBS), Hank's balanced salt solution (HBSS) 등은 모두 Hyclone (Logan, UT, USA)의 제품을 구입하여 사용하였다 RAW264.7 세포주는 $10 \% \mathrm{FBS}$ 와 100 unit의 penicillin과 streptomycin이 함유된 RPMI 1640 media를 사용하여 $5 \%$ 의 이산화탄소를 포함한 $37^{\circ} \mathrm{C}$ 의 포화습 도 공기조건하에서 배양하였다.

\section{Nitric oxide (NO) 생성량 측정 및 cell viability 측정}

$\mathrm{NO}$ 의 생성은 비색법으로 세포 상등액에 축적되는 nitrite 양을 측정하였다. 대식세포를 세포 배양판에 $5 \times 10^{5} \mathrm{cells} / \mathrm{ml}$ 의 세포가 되도록 재부유하여 LPS의 자극하에 24시간 배양하고 그 배양 상층액 내의 $\mathrm{NO}$ 를 Griess 시약과 반응시켜 측정하였 다[25]. $100 \mu 1$ 의 세포배양 상층액을 취하여 동량의 Griess 시 약 $[1 \%$ sulfanilamide ( $30 \%$ acetic acid)와 0.1\% N-(1-naphthyl) ethylenediamine dihydrochloride (60\% acetic acid) 혼합액] 을 가하여 상온에서 20 분간 반응시켰다. $\mathrm{NO}$ 의 활성 정도는 ELISA 판독기를 사용하여 $800 \mu \mathrm{g} / \mathrm{ml}$ 농도 범위에서 $540 \mathrm{~nm}$ 흡광도를 측정하였다.

세포독성 실험은 mitochondrial dehydrogenase activity의 index를 나타내는 MTT colorimetric reduction assay 법으로 시료가 세포생존율에 미치는 영향을 분석하였다[25]. 96-well microtiter plate (Nunc, Vangaard, Neptune, NJ)에 RAW 264.7 macrophage를 $1 \times 10^{5}$ cells/well의 농도로 분주하였다.
분주 24시간 후 각 시료가 함유되어 있는 배지를 $100 \mu 1$ 씩 넣어

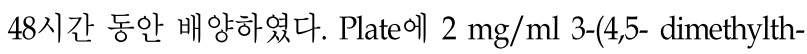
iazol-2-yl)-2,5-diphenyl-tetrazolium bromide (MTT, Sigma) 용 액을 $20 \mu \mathrm{l}$ 씩 첨가하여 4 시간 동안 배양시키고 formazan을 형성시키 후 조심스럽게 상등액을 제거하였다. DMSO $150 \mu \mathrm{l}$ 을 첨가하여 formazan을 녹인 후 $570 \mathrm{~nm}$ 에서 흡광도를 측정 하였다.

\section{혈전분해능 측정}

혈전용해 활성의 측정에 있어서는 Astrup와 Hullertz의 방 법[3]을 변형하여 사용하였다. $0.4 \%$ Fibrinogen (Sigma)을 sodium borate buffer (10 mM sodium borate, $160 \mathrm{mM}$ boric acid, $40 \mathrm{mM} \mathrm{NaCl}$. Merk)에 녹인 다음 직경 $87 \times 10 \mathrm{~mm}$ petridish에 $10 \mathrm{ml}$ 을 넣은 후 thrombin (1,000 unit/ml Sigma) 20 unit를 첨가하여 실온에 30 분간 방치하여 응고시켰다. 응고 된 fibrin plate 에 각 시료를 적당량 점적하여 $37^{\circ} \mathrm{C}$ 에서 반응시 켜 용해된 분해면적을 측정하였으며, 활성의 세기를 측정하기 위하여 혈전분해효소 plasmin과 비교 후 unit로 환산하여 단 위를 정하였다.

\section{SOD 유사활성(Superoxide dismutase -like activity: SODA) 측정}

추출물의 SOD 유사활성은 Marklund 와 Marklund의 방법 [24]에 따라 과산화수소 $\left(\mathrm{H}_{2} \mathrm{O}_{2}\right)$ 로 전환시키는 반응을 촉매하는 pylogallol의 생성량을 측정하여 SOD 유사활성으로 나타내었 다. 시료를 농도별로 희석하여, 시료 $10 \mu 1$ 에 $\mathrm{pH} 8.5$ 로 보정한 Tris- $\mathrm{HCl}$ buffer (50 $\mathrm{mM}$ tris [hydroxymethyl] aminomethane, $10 \mathrm{mM}$ EDTA, pH 8.5) $150 \mu \mathrm{l}$ 와 $7.2 \mathrm{mM}$ pyrogallol $10 \mu 1$ 를 첨가하여 $25^{\circ} \mathrm{C}$ 에서 10 분간 반응시킨 후 $1 \mathrm{~N} \mathrm{HCl} 50$ $\mu 1$ 를 가하여 반응을 정지 시켰다. 반응액 중 산화된 pyrogallol 의 양은 ELISA reader를 사용하여 $420 \mathrm{~nm}$ 에서 흡광도를 측정 하였다. SOD 유사활성은 시료 첨가구와 무첨가구 사이의 흡 광도 차이를 백분율 $(\%)$ 로 나타내었다.

$$
\text { SODA }(\%)=\left(1-\frac{A}{B}\right) \times 100
$$

$\mathrm{A}$ : 시료 첨가구의 흡광도, $\mathrm{B}$ : 시료 무첨가구의 흡광도

\section{Xanthine Oxidase 억제 활성}

Xanthine oxidase에 의해 생성된 superoxide radials 소거활 성은 NBT (nitro-blue tetrazolium) 환원법[28]을 사용하여 검 정하였다. 즉, $0.8 \mathrm{mM}$ xanthine을 포함하는 $0.1 \mathrm{mM}$ phosphate buffer ( $\mathrm{pH} 8.0) 0.5 \mathrm{ml}$ 와 $0.48 \mathrm{mM} \mathrm{NBT}$ 를 포함하는 $0.1 \mathrm{mM}$ phosphate buffer $(\mathrm{pH}$ 8.0)에 시료를 농도별로 각각 처리하여 혼합한 후, $37^{\circ} \mathrm{C}$ 에서 5 분간 incubation 하였다. 반응 물에 xanthine oxidase $(0.049 \mathrm{U} / \mathrm{ml})$ 을 $1.0 \mathrm{ml}$ 을 가하여 $37^{\circ} \mathrm{C}$ 에 서 20 분간 incubation시켰다. 그 후, $69 \mathrm{mM} \mathrm{SDS}$ 를 $2.0 \mathrm{ml}$ 을 
첨가하여 반응을 정지 시킨 후 $560 \mathrm{~nm}$ 흡광도에서 측정하였 다. 농도별 시료에 따른 NBT 환원에 대한 저해능은 다음과 같은 식으로 계산하였다.

$$
\begin{aligned}
& \text { XO inhibition }(\%)=\frac{C-S}{C-B} \times 100 \\
& \text { B (blank): } 0.8 \mathrm{mM} \text { xanthine 포함한 } 0.1 \mathrm{mM} \text { buffer }(\mathrm{pH} \\
& \text { 8.0)와 } 69 \mathrm{mM} \mathrm{SDS} \text { 만 첨가한 반응액 흡광도 } \\
& \mathrm{C} \text { (control): 시료대신 } 0.48 \mathrm{mM} \mathrm{NBT} \text { 를 첨가한 반응액 흡 } \\
& \text { 광도 } \\
& \text { S (Sample): 시료 첨가한 반응액 흡광도 }
\end{aligned}
$$

\section{ACE(Angiotensin I-Converting Enzyme) 저해능 측정}

$\mathrm{ACE}$ 저해 활성은 Cushman 등의 방법[6]에 따라 측정하였 으며, 조효소액은 rabbit lung acetone powder (Sigma, USA) 를 $0.3 \mathrm{M} \mathrm{NaCl}$ 을 함유한 $0.1 \mathrm{M}$ sodium borate buffer $(\mathrm{pH}$ $8.3)$ 에 $1 \mathrm{~g} / \mathrm{ml}(\mathrm{w} / \mathrm{v})$ 의 농도로 $4^{\circ} \mathrm{C}$ 에서 24 시간 추출한 후, $4^{\circ} \mathrm{C}$, $4,000 \mathrm{rpm}$ 에서 40 분간 원심 분리하여 상등액을 $\mathrm{ACE}$ 조효소액 으로 사용하였다. 기질은 $0.3 \mathrm{M} \mathrm{NaCl}$ 이 함유된 $0.1 \mathrm{M}$ sodium borate buffer (pH 8.3)에 HHL (hippuryl- histidyl-leucine)을 $5 \mathrm{mg} / \mathrm{ml}$ (w/v)의 농도로 녹인 후 기질로 사용하였다. ACE 저해활성은 시료 $50 \mu 1$ 에 $\mathrm{ACE}$ 조효소액 $50 \mu \mathrm{l}$ 를 가한 다음 $37^{\circ} \mathrm{C}$ 에서 5 분간 예비반응 시킨 후, 기질 $50 \mu 1$ 을 가한 후 다시 $37^{\circ} \mathrm{C}$ 에서 1 시간 반응 시켰다. $1 \mathrm{~N} \mathrm{HCl} 150 \mu 1$ 로 반응을 정지시 키고 ethyl acetate $750 \mu \mathrm{l}$ 가한 후, 1 분간 교반하고 $4^{\circ} \mathrm{C}, 5,000$ $\mathrm{rpm}$ 에서 10 분간 원심 분리 한 후 상등액 $500 \mu 1$ 를 얻었다. 이 상등액을 $120^{\circ} \mathrm{C}$ 에서 30 분간 완전히 건조시켜 $\mathrm{MeOH} 2 \mathrm{ml}$ 을 넣은 후 $228 \mathrm{~nm}$ 에서 흡광도를 측정하였다. 대조구로서는 시료 대신 시료용매 $50 \mu 1$ 를 가해 실험 하였으며, $\mathrm{ACE}$ 저해 활성효 과는 다음 계산식을 이용하여 실험하였다.

ACE inhibition (\%) $=(C-S / C-B) \times 100$

S: Sample absorbance. C: Control absorbance.

B: Blank absorbance

\section{HPLC 분석}

Flavonoid glycoside 분석을 위한 표준용액 $(1 \mathrm{mg} / \mathrm{ml})$ Quercetin, Kaemferol, Myricetin, Apigenine, Luteolin, Rutin을 메탄올에 용해시켜 사용하였고, 시료 $(10 \mathrm{mg} / \mathrm{ml})$ 는 메탄올에 용해 한 후 Sea-pak C18 cartridge와 $0.2 \mu \mathrm{m}$ filter 로 여과하여 HPLC 분석용 시료로 사용하였다. 분석용 column은 Octadecylsilane (ODS) C18 $(4.6 \times 25 \mathrm{~cm}, 5 \mu \mathrm{m})$ 을 사 용하였고, 용매는 $\mathrm{MeOH} / \mathrm{H}_{2} \mathrm{O} /$ Acetic acid $(5 / 93 / 2, \mathrm{v} / \mathrm{v})$ 와 $60 \% \mathrm{MeOH}$ 를 사용하여 linear gradient해서 55 분간 용출 시 킨 후 15 분간은 $60 \% \mathrm{MeOH}$ 로서 용출하였다. Total flow rate 은 $1 \mathrm{ml} / \mathrm{min}$ 로 하였고, detector는 UV $370 \mathrm{~nm}$ 에서, column temp. oven은 $30^{\circ} \mathrm{C}$ 로 하여 Shimadzu LC-10AD으로 분석하 였다.

\section{결과 및 고찰}

\section{$\mathrm{DPPH}$ 에 의한 항산화 활성}

인체내의 free radical은 지질, 단백질등과 반응하여 생체의 노화를 촉진할 수 있는 물질로, 이러한 free radical를 제거할 수 있는 천연물질에 대한 연구가 활발히 진행되고 있다. 특히 DPPH (1,1-diphenyl-2-picrylhydrazyl) radical 소거법은 항산 화물질의 전자공여능을 이용한 항산화 측정법으로써 주로 pheonlic 구조와 aromatic amine 화합물에서 많이 사용되는 방법이다. 본 연구에서 산야 발효액의 항산화 효과를 $\mathrm{DPPH}$ radical 제거 정도를 측정하여 전자공여능으로 나타낸 결과 발효 원액에서 $94.3 \%$ 로 나타났다(Fig. 1). 일반적으로 이용되 는 positive control인 BHA $0.1 \%$ 에서 항산화 활성이 $96.2 \%$ 로 나타나고 있어서 이와 비슷한 수준으로 보이고 있는 산야 발 효액은 상당히 높은 항산화 활성을 나타내고 있어 그 이용가 치가 높음을 시사하고 있다. 특히, 발효액에서 더 높은 항산화 능을 보이고 있는데 이는 발효중 미생물들의 작용을 통해서 생성된 새로운 활성 성분에 기인하는 것으로 판단된다.

Moon [26], Yoo [37], Kwak [16], Yen [36]등의 보고에 의하 면 감초, 녹차, 박하, 솔잎의 추출물의 활성이 높은 것으로 나 타나 본 연구의 시료인 산야 발효액은 항산화 활성과 관련된 물질이 많을 것이라 사료된다. 특히, 활성산소와 쉽게 반응하 는 물질로는 flavone 및 flavonol 같은 페놀성 화합물을 들 수 있는데 각 생약재에 함유되어 있는 이들 페놀성 화합물 및 플라보이드류가 항산화 활성을 나타내는 물질로 추정된다.

\section{플라보노이드 함량 분석}

지금까지의 보고에 의하면 항산화능과 플라보노이드의 함 량에는 비례적인 연관성이 있다고 알려져 왔다[23]. 이에 본 연구에서는 항산화능이 우수한 산야 발효액에 대한 플라보노 이드 함량을 HPLC로 정량 분석하였다(Table 1). Quercetin은 산야 발효액에서 $87 \mu \mathrm{g} / \mathrm{g}$ 의 함량을 보였지만, Kaemferol와 myricetin은 관찰되지 않았다. Apigenine의 함량 분석과정에 서 산야 발효액의 결과 $484 \mu \mathrm{g} / \mathrm{g}$ 으로 높은 함량을 나타내었



Fig. 1. DPPH electron scavenging ability of fermented medical plants (FSY) depending on concentration. Results are mean \pm S.D. of triplicate data. 
Table 1. Flavonol glycosides content of fermented medical herbs $(\mu \mathrm{g} / \mathrm{g})$

\begin{tabular}{cccccccc}
\hline Flavonoids & Quercetin & Kaemferol & Myricetin & Apigenine & Luteolin & Rutin & Total \\
\hline FSY & 87 & - & - & 484 & 222 & 3,853 & 4,646 \\
\hline
\end{tabular}

Flavonol glycosides were analyzed by LC. FSY: fermented medical herbs (SanYa)

다. Luteolin의 경우에서도 $222 \mu \mathrm{g} / \mathrm{g}$ 으로 높은 함량이 관찰되 었다. 대표적인 플라보노이드계 물질인 Rutin은 $3,853 \mu \mathrm{g} / \mathrm{g}$ 으 로 훨씬 높은 함량을 보이고 있는데, 이로써 총 플라보노이드 의 함량은 산야 발효액에서 $4,646 \mu \mathrm{g} / \mathrm{g}$ 으로, 이는 Fig. 1에서 보이는 높은 라디칼 소거능과 일치한다. 따라서, 자연에 존재 하는 대부분의 플라보노이드가 나타내는 항산화능은 라디칼 의 소거능이 큰 것에서 찾아 볼 수 있다고 생각할 수 있다. 이러한 결과는 Kang [10]이 감귤껍질에서 플라보노이드를 분 리 추출하여 실시한 산화억제능에서도 동일한 결과를 나타낸 바 있다. Kim 등[12]이 대두에서 각종 용매를 이용하여 플라보 노이드를 추출하여 실험한 항산화능에서도 동일한 결과를 나 타내었으며 붉나무 순차용매 추출물의 항산화 효과를 비교한 Lee 등[21]의 연구결과에서도 이러한 사실을 입증한 바 있다.

\section{대식세포에서의 Nitric oxide 생성능 측정}

대식세포를 이용하여 Nitric oxide (NO) 생성능을 확인한 결과를 Fig. 2에 나타내었다. NO는 면역 세포에서 NOS (nitric oxide syntase)에 의해 생성되는데 다량으로 외부의 자극에 의해 유전자 수준에서 발현되고 주로 침입한 미생물이나 종양 세포에 대해 독성을 갖는 방어 물질로서 작용하는 것으로 알 려져 있다[7,22]. 또한, 최근에는 $\mathrm{NO}$ 가 세포 활성화 물질 및 reactive oxygen intermediates (ROI)에 의해 유발된 세포 독성 을 최소화 시키는 역할이 밝혀짐으로 이 분야에 대해서 활발 히 연구되고 있다[15,35]. 이에 본 실험에서는 시료를 대식세포 에 투여하여 $\mathrm{NO}$ 의 생성능을 확인하였다. 결과에서도 확인할 수 있는 것처럼 대식세포가 생성하는 $\mathrm{NO}$ 량 $2 \mu \mathrm{m}$ 보다 발효액

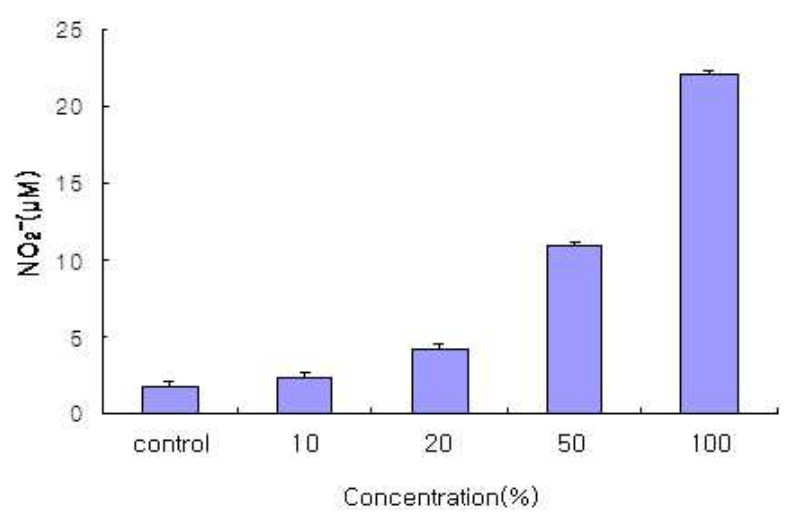

Fig. 2. Stimulation of NO synthesis by fermented medical plants (FSY) depending on concentration. NO production was determined in macrophage RAW 264.7 cells. Results are mean \pm S.D. of triplicate data.
의 첨가로 인해 $22.0 \mu \mathrm{m}$ 의 높은 $\mathrm{NO}$ 생성능을 나타내었다(Fig. 2). 이로써, 산야가 면역활성과 관련하여 활용 가능성이 있으 며 전통발효를 통해 높은 면역활성의 증진이 있음을 확인할 수 있었다. 지금까지의 연구는 주로 침입한 미생물이나 종양 세포가 분비하는 독성물질로 유발되는 NO 생성을 저해하는 효능에 대해 조사해 왔으며, 방어 물질로 또는 독성을 최소화 시킬 수 있는 물질로써의 NO 생성 활성에 대한 연구는 거의 없는 것으로 판단된다.

\section{NO Assay 및 cell viability}

대장균 Bacterial lipopolysaccharide (LPS)를 대식세포에 처리하여 $\mathrm{NO}$ 를 유도시킨 다음 산야 발효액을 대식세포에 처 리하여 NO 활성에 미치는 영향을 조사하였다(Fig. 3). 그 결과, LPS에 의하여 유도된 대식세포의 NO 합성은 산야 발효액을 농도별로 첨가하였을 때 점차 감소하였다. 발효액의 첨가로 $56 \%$ 의 NO 생성 저해능을 나타났으며(Fig. 3), 이러한 결과는 산야로 부터의 성분들이 면역기능과 밀접한 관계가 있음을 보여주는 것이다. NO는 L-arginine의 guanidino nitrogen으 로부터 nitric oxide synthase (NOS)에 의하여 생성되며[14], $\mathrm{NO}$ 는 분비조직과 세포의 기능에 영향을 미치며, 세포성 면역 계의 주된 역할의 하나로 세포 독성이나 성장 억제 작용을 한다[9]. NO는 대부분의 포유류 동물의 세포내에서 생성되고 신경계에서는 화학적 신호 전달 물질로서, 혈관계에서는 혈압 조절과 혈소판의 응집 및 호중성구의 집합 작용을, 골격근에 서는 대사와 근 수축 조절 등 생리학적으로 중요한 역할을 한다. NO가 발현하는 기능의 다양성은 농도 및 표적세포의

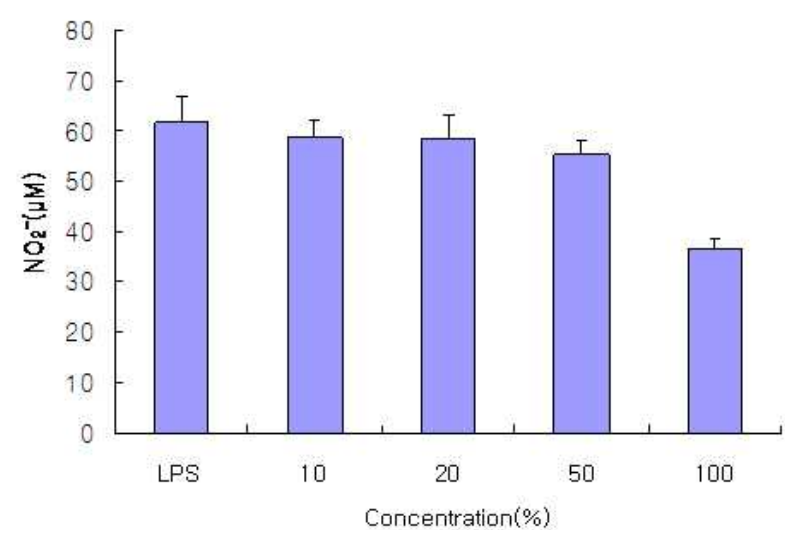

Fig. 3. Effects of fermented medical plants (FSY) depending on concentration on NO synthesis in RAW 264.7 cells stimulated with LPS. Results are mean \pm S.D. of triplicate data. 
활성화여부에 따라 달라진다고 알려져 있다. 대식세포가 pathogen에 의하여 활성화되면 NO 뿐만 아니라 superoxide anion을 호흡과정에 의하여 대량생산되는데, $\mathrm{NO}$ 자신은 매우 약한 산화성을 가진 라디칼로서 vitamin $\mathrm{E}$ 와 비슷하게 세포의 지질과산화물을 막는 항산화 기능도 수행한다는 보고도 있다. 최근 염증반응을 완화시키는데 있어서도 종래에 사용되어온 $\mathrm{NO}$ 를 소거하는 방식보다는 superoxide anion의 생성을 저해 하거나 NADPH oxidase의 활성을 감소시키는 방법[34]이 더 욱 비중 있게 다루어지고 있다.

LPS에 의한 산야 성분의 NO 합성 저해효과 또한 연구되어 왔는데 Seo 등[32]은 $50 \%$ 이상의 NO 생성 저해능을 $100 \mu \mathrm{g} /$ $\mathrm{ml}$ 의 봉선화, 금불초, 산옥잠화, 모시풀등과 같은 약초의 메틸 추출물에서 보고하였다. 이는 본 연구에서 이용된 시료보다 높은 NO 합성 저해율을 나타내고 있다. Ahn 등[1]은 도라지의 $\mathrm{NO}$ 합성 저해율을 보고하였는데, 우수한 NO 합성 저해율로 차세대 염증질환 치료제와 예방약으로 활용할 수 있을 것으로 판단하고 있다. 이는 역시 본 연구에서 분석된 산야의 활용도 를 대변하고 있다.

발효액 시료에 대한 세포활성은 MTT 분석을 통해서 측정 하였다. 그 결과 시료로 처리된 대식세포의 세포생존율이 $90 \%$ 정도를 나타내는 바 본 연구에서 사용된 시료에 대한 세포독 성은 없는 것으로 관찰되었다. 또한, 실험결과에 나타난 $\mathrm{NO}$ 의 생성량의 변화가 세포독성에 의한 영향과는 무관함을 확인 할 수 있었다.

\section{혈전분해능 측정}

혈전은 혈관손상으로 혈액이 유출될 때 합성되는 섬유성 단백질인 피브린으로 알려져 있다. 이들 피브린은 그대로 두 면 다시 용해되는데 이는 혈장 속에 있는 플라스미노겐이 활 성화하여 plasmin이 되어 피브린을 분해시키기 때문이다. 하 지만 어떤 장애로 인한 불균형으로 인하여 혈전이 분해되지 않고 응집되어 혈관에 축적됨으로서 혈전증을 야기시킨다 [31]. 이에 본 연구에서는 산야의 혈전분해능을 조사하고자 하 였으며, 그 결과 산야 발효액에서 혈전분해능이 나타났다(Fig. 4). 특히, 산야 열수 추출물과 positive control인 plasmin을 비교 분석용으로 사용하였는데, plasmin $1 \mu \mathrm{g}$ 과 산야 열수 추 출물 $10 \mathrm{mg} / \mathrm{ml}$ 의 혈전분해능과 비교실험을 실시한 결과 산 야 발효액에서 높은 혈전분해능을 나타냈다. 발효액의 혈전분 해능은 체온과 유사한 온도인 $37^{\circ} \mathrm{C}$ 에서 2시간 반응 후 확인되 고 있는데, 이는 plasmin보다 더 효율적으로 보인다. 이에 반 해 추출물에서는 혈전분해능을 보이지 않고 있어 산야 발효액 의 혈전분해능은 발효 중 생성된 균주들의 혈전분해능으로 사료된다. 지금까지의 보고에 의하면 된장으로부터 분리된 Bacillus 속 KDO-13 [18], 치즈로부터 분리된 B. amyloliquefaciens DC-4 [30], 흑두로 제조한 청국에서 분리된 B. subtilis BB-1 [20], 멸치액젓으로부터 분리된 B. subtilis JM-3 [19], 청국

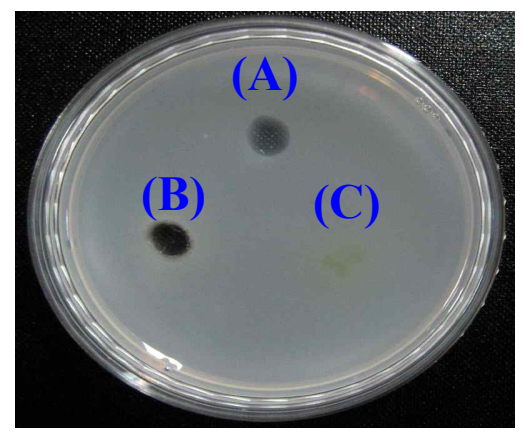

Fig. 4. Fibrinolytic activites of fermented medical plants (FSY) and hot water extract from SanYa. (A), $1 \mu \mathrm{g}$ of plasmin; (B), fermented SanYa (FSY); (C), $10 \mathrm{mg} / \mathrm{ml}$ of hot water extract from medical plants (SYW). $20 \mu \mathrm{l}$ of test samples was dropped onto the fibrin plate and the plate was incubated for $2 \mathrm{hr}$ at $37^{\circ} \mathrm{C}$.

장으로부터 분리된 B. subtilis KCK-7 [27] 등이 혈전분해능이 우수한 것으로 알려져 있다.

\section{SOD 유사활성(Superoxide dismutase-like activity: SODA) 측정}

Superoxide dismutase (SOD)는 항산화 효소로서 세포에 유해한 oxygen radical을 과산화수소 전환시키고 다시 catalase에 의하여 무해한 물 분자와 산소분자로 전환시켜 활성산 소로부터 생체를 보호하는 기능으로 알려져 있다. SOD는 분 자량이 비교적 큰 단백질로서 열이나 알칼리에 약하여 이러한 단점을 보완할 수 있는 저분자물질로 체내에서 역할이 유사한 $\mathrm{SOD}$ 유사활성 물질에 대한 연구가 진행되고 있다.

본 연구에서 산야 발효액의 SOD 유사활성은 최고농도에서 $42.2 \%$ 의 활성을 보였으며 $\mathrm{SOD}$ 활성은 농도 의존적으로 항산 화 활성이 증가하였다(Fig. 5). 대조구인 Vit. C의 경우 농도 $0.1 \%$ 일 때 $77.3 \%$ 로 보고되어 있는데, 산야 발효액과의 비교 결과에 따르면 대조구 보다 낮은 SOD 유사활성을 나타내고 있다. 하지만, 이러한 결과는 비교적 항산화력이 높은 과일로 알려진 브로콜리, 딸기 착즙액의 SOD 유사활성 $(41.4 \%, 30 \%)$

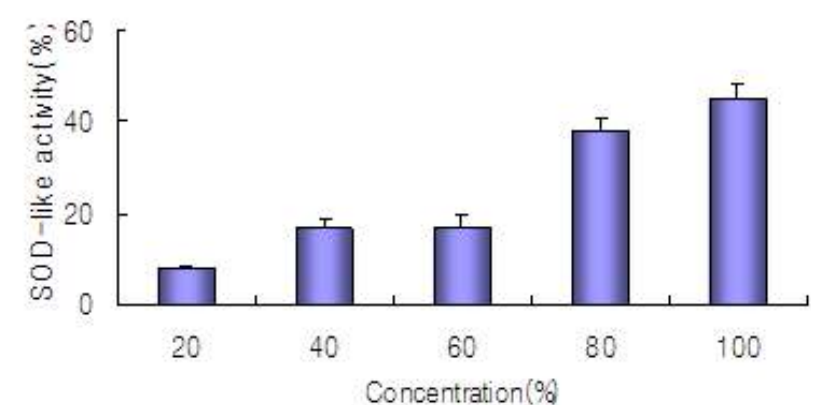

Fig. 5. Superoxide dismutase (SOD)-like activity of fermented medical plants (FSY) depending on concentration. Results are represented as means \pm S.D. of three independent experiments. 
보다 약간 높은 SOD 유사활성을 나타낸다[11].

지금까지의 산야에 대한 $\mathrm{SOD}$ 활성은 추출물에서 분석되어 왔으며, 발효액에 대한 보고는 거의 없는 와중에 Kim 등[13]은 산야채 추출물을 발효시킨 발효액 중에 아카시아와 감잎 등에 서 각각 $25.1 \%, 29.2 \%$ 의 SOD 유사활성을 나타내었다고 보고 하였다. 이 결과로 보아 본 연구의 산야 발효액의 SOD 활성이 훨씬 더 우수하다고 판단되며 그 이용가치가 높음을 증명하고 있다.

\section{Xanthine oxidase 저해 활성}

Xanthine oxidase는 purine 대사에 관여하는 효소로서 xanthine 또는 hypoxanthine의 산소를 때어내면서 과산화수소 $\left(\mathrm{H}_{2} \mathrm{O}_{2}\right)$ 를 생성하게 되고, 나머지 골격이 uric acid를 형성하여 혈장 내에 과량 존재하게 되면 골절에 축적되어 심한 통증을 유발하는 통풍과 신장에 침착되어 신장질환을 일으키는 효소 로 알려져 있다. Xanthine oxidase 저해활성 측정은 일종의 항산화 능을 측정하는 방법으로 본 실험에서는 대조구로 catechin을 사용하였으며 산야 발효액과 농도별로 비교하였다. Xanthine oxidase저해 활성 측정 결과 농도가 증가할수록 저 해활성이 증가하였으며, 대조구인 catechin과 비교한 결과 1 $\mathrm{mg} / \mathrm{ml}$ 에서 $79.8 \%$ 인 반면, 100 배 희석한 산야 발효액은 $75.6 \%$ 로 높게 나타났다(Fig. 6). Catechin은 polyphenol계 항산화 물질로써 식물성 대사산물로 알려져 있으며 항산화효과가 비 타민 E에 비해 무려 50배나 되고, 비타민 C에 비해 100 배에 달하기 때문에, 체내의 활성산소를 제거하는 효과가 매우 탁 월하다고 알려져 있다[29]. 특히, 산야 발효액의 XOase 저해효 과는 catechin의 효과보다 높은 결과를 나타내고 있어 본 연구 의 산야 발효액이 우수한 항산화 소재로 개발될 수 있을 것으 로 기대된다.

\section{ACE 저해작용}

$\mathrm{ACE}$ 는 renin에 의하여 생성된 angiotensin I으로부터 C-말 단 dipeptide (His-Leu)를 가수분해 시킴으로서 강력한 혈관

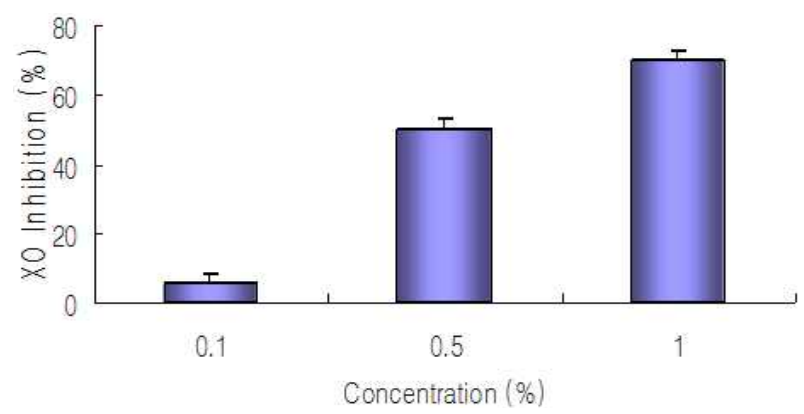

Fig. 6. Xanthine oxidase inhibitory activity of fermented medical plants (FSY) depending on concentration. Results are represented as means \pm S.D. of three independent experiments.

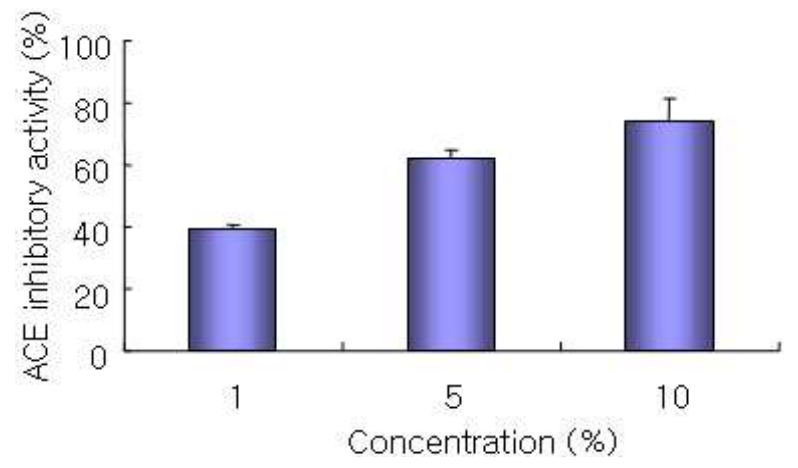

Fig. 7. Angiotensin converting enzyme inhibitory activity of fermented medical plants (FSY) depending on concentration. Results are represented as means \pm S.D. of three independent experiments.

수축작용을 나타내는 angiotensin II를 생성하여 고혈압의 원 인이 되고 있다. Angiotensin ㅍㄴ는 혈관을 수축시키는 작용을 하고, 부신에서 aldosterone의 분비를 촉진시켜 체내 수분 보 유량을 많게 하여 결과적으로 혈압을 상승시키는 작용을 한 다. $\mathrm{ACE}$ 의 작용이 계속 지속화 될 경우 고혈압이 지속되어 혈관벽이 약화되어 터지게 되거나, 뇌졸중 등의 여러 질환을 유발시킬 수 있다. 이러한 $\mathrm{ACE}$ 의 활성 저해인자로는 저분자 peptide들과 그 유도체들, 녹차에 존재하는 catechin과 메밀의 rutin과 같은 polyphenol 성분들이 대표적으로 알려져 있다. 이러한 $\mathrm{ACE}$ 의 작용을 억제하기 위한 활성이 산야에 있는 지 알아보기 위해 실험을 한 결과, 산야 발효액에서 높은 활성을 나타내었다(Fig. 7). 대조구로 현재 시판되고 있는 항고혈압제 인 captopril을 사용하였으며, captopril $10 \mu \mathrm{g} / \mathrm{ml}$ 에서 93.0\% 의 저해 활성을 보였는데 10 배 희석한 산야 발효액에서 $73.5 \%$ 의 저해 활성을 보였다. 이러한 결과는 고혈압 예방 효능이 높은 기능성 식품인 유색감자 보다 뛰어난 효능을 나타내고 있다[28]. 따라서 본 연구에서 개발된 산야 발효액은 고혈압 예방 기능성 음료로서 이용가능성이 높은 것으로 사료된다.

\section{References}

1. Ahn, K. S., E. J. Noh, H. L. Zhao, S. H. Jung, S. S. Kang, and Y. S. Kim. 2005. Inhibition of inducible nitric oxide synthase and cyclooxygenase II by Platycodon grandiflorum saponins via suppression of nuclear factor-kB activation in RAW 264.7 cells. Life Sci. 76, 2315-2328.

2. Ahn, S. W., M. H. Kim, W. T. Chung, B. Hwang, N. S. Seong, and H. Y. Lee. 2000. Enhancement of alcohol fermentation yield by adding the extract of dried Rehmannia glutinosa Liboschitz. Kor. J. Medicinal Crop Sci. 8, 351-361.

3. Astrub, T. and S. Hullertz. 1952. The fibrin plate method for estimating fibrinolytic activity. Arch Biochem Biophy. 40, 346-351.

4. Bae, I. Y., E. J. Yoon, J. M. Woo, J. S. Kim, H. G. Lee, and 
C. B. Yang. 2002. The development of Korean traditional wine using the fruits of Opuntia ficus-indica var, saboten-I. Characteristics of mashes and sojues. J. Korean Soc. Appl. Biol. Chem 45, 11-17.

5. Blois, M. S. 1958. Antioxidant determination by the use of a stable free radical. Nature 26, 1199-1200.

6. Cushman, D. W. and H. S. Cheung. 1971. Spectrophotometric assay and properties of the angiotensin-converting enzyme of rabbit lung. Biochem Pharmacol. 20, 1637-1648.

7. Hierholzer, C., B. Harbrecht, J. M. Menezes, J. Kane, J. MacMicking, C. F. Nathan, A. B. Peitzman, T. R. Billiar, and D. J. Tweardy. 1998. Essential role of induced nitric oxide in the initiation of the inflammatory response after hemorrhagic shock. J. Exp. Med 187, 917-928.

8. Hong, S. W., J. Y. Kim, B. K. Lee, and K. S. Chung. 2006. The bacterial biological response modifiee enriched chungkookjang fermentation, Korean J. Food Sci. Technol. 38, 548-553.

9. Jeon, J. R., J. Y. Kim, K. M. Lee, and D. H. Cho. 2005. Anti-obese effects of mixture contained pine needle, black tea, and green tea extracts. J. Kor. Soc. Appl. Biol. Chem 48, 375-381.

10. Kang, J. H. 1993. Studies on the antioxidative effect and the inhibitory effect on the DNA damage of bioflavonoid extracted from Citrus sinensis. Kosin J. Health Sci. 3, 74-81.

11. Kim, J. D., T. H. Yoon, M. Choi, K. J. Lim, J. S. Ju, and S. Y. Lee. 1990. Effect of dietary supplementation with pine leaf on lipid parameters in rat. Kor. J. Gerontol. 1, 47-50.

12. Kim, J. Y., Y. S. Maeng, and G. Y. Lee. 1995. Antioxidative effects of soybean extracts by using various solvents. Kor. J. Food Sci. Technol. 27, 635-639.

13. Kim N.-M., J.-W. Lee, J.-H. Do, and J.-W. Yang. 2003. Effects of the fermentation periods on the qualities and functionalities of the fermentation broth of wild vegetables. Kor. J. Food Sci. Technol. 35, 272-279.

14. Kim, Y. S. and D. H. Shin. 2004. Volatile components and antibacterial effects of pine needle (Pinus densflora S. et Z.) extracts. Food Microbiol. 22, 37-45.

15. Krncke, K. D., K. Fehsel, and V. Kolb-Bachofen, 1997. Nitric oxide: cytotoxicity versus cytoprotection-How, why, when, and where? Nitric Oxide. 1, 107-120.

16. Kwak, C. S., S. C. Moon, and M. S. Lee. 2006. Antioxidant, antimutagenic, and antitumor effects of pine needles (Pine densiflora). Nutr. Cancer 56, 162-171.

17. Lee, S. E., H. J. Hwang, J.-S. Ha, H.-S. Jeong, and J. H. Kim. 2003. Screening of medical plant extracts for antioxidant activity. Life Sci. 73, 167-179.

18. Lee, S.-K., D.-H., Bae, T.-J. Kwon, S.-B. Lee, H.-H. Lee, J.-H. J.-H. Park, and S. Heo. 2001. Purification and characterization of a fibrinolytic enzyme form Bacillus sp. KDO-13 isolated from soybean paste. J. Microbiol. Biotechnol. 11, 845-845.

19. Lee, S. S., S. M. Kim, U. K. Park, H. Y. Kim, and I. S. Shin. 2002. Studies on proteolytic and fibrinolytic activity of Bacillus subtilis JM-3 isolated from anchovy sauce. Kor. J. Food Sci. Technol. 34, 283-289.
20. Lee, Y. H., S. H. Lee, J. M. Jeon, H. C. Kim, Y. U. Cho, K. H. Park, Y. J. Choi, and S. W. Gal. 2005. Cloning and characterization of a gene for fibrinolytic enzyme from Bacillus subtilis BB-1 isolated from black bean Chung-kuk J. Life Sci. 15, 513-521.

21. Lee, Y. J., D. H. Shin, Y. S. Chang, and W. S. Kang. 1993. Antioxidative effect of Rhus javanica Linne extract by various solvents. Kor. J. Food Sci. Technol. 25, 677-682.

22. Luss, H., N. C. Nussler, H. G. Beger, and A. K. Nussler. 1996. Expression and detection of inducible nitric oxide synthase in experimental models of inflammation. Methods 10, 51-60.

23. Makris, D. P. and J. T. Rossiter. 2001. Comparison of quercetin and non-orthohydroxy flavonoid as antioxidants by competing in vitro oxidation reactions. J. Agric. Food Chem 49, 3370-3377.

24. Marklund, S. and G. Marklund. 1975. Involvement of superoxide aminoradical in the oxidation of pyrogallol and a convenient assay for superoxide dismutase. Eur. J. Biochem 47, 468-474.

25. Marletta, M. A. 1993. Nitric oxide synthase structure and mechanism. J. Biol. Chem 268, 12231-12234.

26. Moon, J. S., S. J. Kim, Y. M. Park, I. S. Hwang, E. H. Kim, J. W. Park, I. B. Park, S. W. Kim, S. G. Kang, Y. K. Park, and S. T. Jung. 2004. Activities of antioxidation and alcohol dehydrogenase inhibition of methanol extracts from some medicinal herbs. Kor. J. Food Preserv. 11, 201-206.

27. Paik, H. D., S. K. Lee, S. Heo, S. Y. Kim, H. H. Lee, and T. J. Kwon. 2004. Purification and characterization of the fibrinolytic enzyme produced by Bacillus subtilis KCK-7 from ChungKookjang. J. Microbiol. Biotechnol. 14, 829-835.

28. Parejo, I., F. Viladomat, J. Bastida, A. Rosas-Romero, N. Flerlage, J. Burillo, and C. Conida. 2002. Comparision between the radical scavenging activity and antioxidant activity of six distilled and nondistilled Mediterranean herbs and aromatic plants. J. Agric. Food Chem 50, 6882-6890.

29. Park, Y.-E., H.-M. Cho, H.-J. Lee, Y.-S. Hwang, S.-S.-N. Choi, S.-J. Lee, E.-S. Park, J.-D. Lim, and M.-G. Choung. 2007. Antioxidant and inhibition on angiotensin converting enzyme activity of colored potato extracts. Kor. J. Crop Sci. 52, 447-452.

30. Peng, Y., Q. Huang, R.-H. Zhang, and Y.-Z. Zhang. 2003. Purification and characterization of a fibrinolytic enzyme produced by Bacillus amyloliquefaciens DC-4 screened from douchi, a traditional Chinese soybean food. Comparative Biochem Physiol. Part B 134, 45-52.

31. Peng, Y., X. J. Yang, and Y. Z. Zhang. 2005. Microbial fibrinolytic enzymes: an overview of source, production, properties, and thrombolytic activity in vivo. Appl. Microbid. Biotechnol. 69, 126-132.

32. Seo J. S., T. H. Lee, S. M. Lee, S.-E. Lee, N. S. Seong, and J. Y. Kim. 2009. Inhibitory effects of methanolic extracts of medicinal plants on nitric oxide production in activated macrophage RAW 264.7 cells. Kor. J. Medicinal Crop. Sci. 17, 173-178.

33. Sun, T. and S. A. Tanumihardjo. 2007. An integrated ap- 
proach to evaluate food antioxidant capacity. J. Food Sci. $72,159-165$

34. van der Veen, R. C. 2001. Nitric oxide and T cell immunity. Int. Immunophamacol. 1, 1491-1500.

35. Wink, D. A., J. A. Cook, R. Pacelli, W. DeGraff, J. Gamson, J. Liebman, M. C. Krishna, and J. B .Mitchell. 1996. The effect of various nitric oxide-donor agents on hydrogen peroxide-mediated toxicity: a direct correlation between nitric oxide formation and protection. Arch Biochem Biophys. 331, 241-248.
36. Yen, G.-C., P.-D. Duh, D.-W. Huang, C.-L. Hsu, and T. Y.-C. Fu. 2008. Protective effect of pine (Pinus morrisonicola Hay.) needle on LDL oxidation and its anti-inflammatory action by modulation of iNOS and COX-2 expression in LPS-stimulated RAW 264.7 macrophages. Food Chemical Toxicol. 46, 175-185.

37. Yoo, J.-H., J.-Y. Cha, Y.-K. Jeong. K.-T. Chung, and Y.-S. Cho. 2004. Antioxidative effects of pine (Pinus densflora) needle extracts. J. Life Sci. 14, 863-867.

\section{초록 : 산야초를 이용한 기능성 발효음료개발 및 생리활성 연구}

\section{조은경 $\cdot$ 송효주 $\cdot$ 조혜은 $\cdot$ 최인순 ${ }^{2}$ 최영주*}

(신라대학교 의생명과학대학 식품영양학과, ${ }^{1}$ 바이오식품소재학과, ${ }^{2}$ 생물과학과)

지금까지의 연구에 의하면 산야 발효액에 대한 보고가 미비하므로 본 연구에서는 산야의 기능성에 관한 연구 를 위하여 산야 발효액으로 여러 가지 생리활성과 면역활성에 대하여 분석하였다. 우선, 산야의 항산화 활성을 측정하기 위하여 DPPH 활성과 플라보노이드 함량을 측정하였다. 그 결과 DPPH법을 통해 측정한 산야 발효액의 항산화력은 $94.3 \%$ 의 radical 소거능을 나타내었다. BHA와 비교 했을 때 유사한 항산화력이 측정되었는데, 이것 은 항산화 활성이 높은 것으로 산야의 항산화력에 관한 높은 이용가치를 의미한다. 산야 발효액의 총 플라보이드 함량은 $4.646 \mathrm{mg} / \mathrm{g}$ 으로 높았으며, 이는 높은 항산화능과 연관성이 있는 것으로 나타났다. 산야 발효액과 면역활 성과의 연관성은 $\mathrm{NO}$ 합성률과 LPS에 의해 유도되는 NO 합성 저해률 분석으로 조사되었다. 그 결과, 산야 발효 액은 무려 11 배의 높은 NO 합성율을 보였다. 또한 LPS에 의해 유도된 NO 합성 저해율은 $56 \%$ 로 나타나 산야의 높은 면역효과를 증명하고 있다. 혈전분해능에 대한 산야 발효액의 분석 결과는 혈전용해제로 알려져 있는 plas-

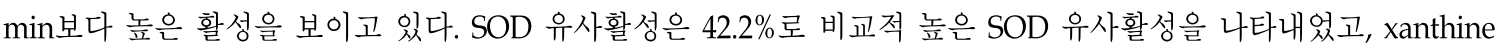
oxidase 저해활성은 $75.6 \%$ 로 높게 나타났다. 항고혈압 측정실험에서는 $73.5 \%$ 의 저해율을 나타내어 ACE 저해 활 성이 뛰어난 것으로 나타났다. 이상의 결과는 산야의 우수한 생리활성을 증명하고 있고, 항산화력, 면역활성 및 항고혈압 효과가 높은 것으로 나타나 기능성 음료의 소재로서 그 활용도가 높을 것으로 판단된다. 